\title{
PENGARUH PENDIDIKAN KESEHATAN TERHADAP PENGETAHUAN DAN SIKAP SISWA TENTANG BAHAYA MEROKOK KELAS XI SMA YAYASAN WANITA KERETA API PALEMBANG TAHUN 2019
}

\author{
Indah Riski Hidayati ${ }^{1}$, Dewi Pujiana ${ }^{2}$, Maya Fadillah ${ }^{3}$ \\ 1,2,3 Nursing Program of STIKes Muhammadiyah Palembang. \\ Jl. Jenderal Ahmad Yani, 13 Ulu, Seberang Ulu II, Kota Palembang, \\ Sumatera Selatan, Indonesia \\ Email: ${ }^{1}$ indahriskih01@gmail.com, ${ }^{2}$ dewipujiana9@gmail.com
}

Tanggal Submisi: 01 Agustus 2018; Tanggal Penerimaan: 11 Desember 2019

\begin{abstract}
ABSTRAK
Kebiasaan merokok pada anak usia sekolah di Indonesia sering terlihat pada siswa SMA, karena pada usia ini merupakan suatu masa peralihan antara masa kanakkanak menuju masa dewasa. World Health Organization (WHO) menyatakan bahwa rokok menyebabkan masalah kesehatan yang fatal yang menjadi penyebab kematian kurang lebih 6 juta orang pertahun. Pendidikan kesehatan dilakukan untuk memepngaruhi pengetahuan dan sikap siswa SMA tentang bahaya merokok. Tujuan penelitian untuk mengetahui pengaruh pendidikan kesehatan terhadap pengetahuan dan sikap siswa tentang bahaya merokok di sekolah SMA YWKA di Palembang tahun 2019. Penelitian ini menggunakan desain one group pre testpost test design without control group. Sampel dalam penelitian ini sebanyak 105 responden. Teknik pengambilan sampel menggunakan accidental sampling, instrument penelitian ini menggunakan lembar kuesioner. Hasil penelitian diperoleh median pengetahuan tentang bahaya merokok sebelum diberikan pendidikan kesehatan sebesar 73,00, dan standar deviasi 6,596. Median pengetahuan tentang bahaya merokok setelah diberikan pendidikan kesehatan sebesar 93,00, dan standar deviasi 5,507. Median sikap tentang bahaya merokok sebelum diberikan pendidikan kesehatan sebesar 70,00, dan standar deviasi 6,734. Median sikap tentang bahaya merokok setelah diberikan pendidikan kesehatan sebesar 90,00, dan standar deviasi 7,407. Ada pengaruh sebelum dan setelah dilakukan pendidikan kesehatan terhadap pengetahuan tentang bahaya merokok di sekolah SMA YWKA di Palembang tahun $2019(\rho=0,000)$ dan Ada pengaruh sebelum dan setelah dilakukan pendidikan kesehatan terhadap sikap tentang bahaya merokok di sekolah SMA YWKA di Palembang tahun $2019(\rho=0,000)$. Berdasarkan hasil disarankan hasil penelitian ini dapat dijadikan tambahan pengetahuan untuk memberikan pendidikan kesehatan bagi siswa tentang bahaya merokok. Baik bagi pihak sekolah maupun siswa.
\end{abstract}

Kata Kunci : Pendidikan kesehatan, Pengetahuan, dan Sikap, Bahaya Merokok

ISSN 1979-7621 (Print). ISSN 2620-7761 (Online). 


\begin{abstract}
Smoking behavior at earlir age is displayed by senior high school students since it is a traditional age from child to young adault. WHO states that smoking has caused fatal health problems which cause approximately six millions deaths per year. Objective : This study aims at finding out the effect of health education toward students' knowledge and attitude on hazard of smoking at YWKA senior high school of palembang in 2019. Methods of Study is a one group pre test-post test design without control group with 105respondence which werechosen using accidential sampling. Futhermore, the data collected using a quistionnair. The resault show that median scores of knoeledge on hazard of smoking before education was 70,00 (SD 6,734) and after education was 93,00(SD 5,507). The resault also indicate of medium scores of attitude on hazard smoking before education was 73,00(SD 6,596) and after education was 90,00(SD7,407). Conclusions : it is concluded there were effect of education toward and knowledge on hazard of smoking $(\rho=0,000)$ and toward attitude on hazard on smoking $(\rho=0,000)$. Based on the resault, it is expeted that the resault can be an additional material for health education for school.
\end{abstract}

Keywords: Health education, Knowledge, and attitude, hazard, smoking

\section{PENDAHULUAN}

Manusia mempunyai banyak macam kebiasaan, adapun berolahraga, membaca, menulis, dan masih banyak lain, akan tetapi ada salah satu kebiasaan yang paling buruk dan sangat merugikan manusia itu sendiri salah satunya merugikan kesehatan dirinya dan orang lain, tetapi kebiasaan tesebut yang buruk tesebut masih dilakukan oleh manusia tersebut yaitu kebiasaan merokok. Rokok merupakan hasil olahan tembakau yang terbungkus, dihasilkan dari tanaman Nicotiana Tabacum, Nicotiana Rustica dan spesies lainnya atau sintetisnya yang mengandung nikotin dan tar dengan atau tanpa bahan tambahan (Heryani, 2014).

Nikotin adalah zat alkaloid yang ada secara natural ditanaman tembakau nikotin juga didapati pada tanamantanaman lain dari famili Solanaceae seperti tomat, kentang, terong dan merica hijau pada level yang sangat kecil dibandingpada tembakau nikotin tidak berwarna tetapi segera menjadi coklat ketika bersentuhan dengan udara. Nikotin dapat menguap dan dapat dimurnikan dengan cara penyulingan uap dari larutan yang dibasakan (Heryani, 2014).

Remaja merupakan laki-laki maupun perempuan berusia sekitar 11 sampai 20 tahun. Masa remaja merupakan masa peralihan sifat maupun perubahan bentuk tubuh. Remaja pria akan mengalami perubahan yang sangat nampak pada suara dan itu bagian dari perubahan fisik yang khas bagi pria (Heryani, 2014).

Remaja yang didefinisikan menurut World Health Organization adalah periode usia berkisar antara 10 sampai dengan 19 tahun, sedangkan Persatuan Bangsa Bangsa mengatakan bahwa kaum muda untuk usianya15 sampai 24 tahun. Menurut The Health Resources and Services Administrations Guidelines Amerika Serikat, rentang usia remaja adalah 11-21 tahun dan terbagi menjadi 3 tahap, yaitu remaja awal (11-14 tahun); remaja menengah (15-17 tahun) dan remaja akhir (18- 21 tahun). (WHO, 
2017). Masa remaja merupakan suatu masa ketika individu mengalami perkembangan psikologis dan pola identifikasi dari kanak-kanak menuju dewasa. Ketidak stabilan emosi, adanya sikap mnentang, kegelisahan, senang bereksperimentasi, senag bereksplorasi, mempunyai banyak khayalan (Gunarsa, 2014). Remaja yang suka bereksperimentasi selalu ingin mencobacoba akan memebentuk sebuah perilaku seperti perilaku merokok.

Kebiasaan merokok pada anak usia sekolah di Indonesia sering terlihat pada siswa SMA, karena pada usia ini merupakan suatu masa peralihan antara masa kanak-kanak menuju masa dewasa. Masa remaja termasuk masa yang sangat menentukan karena pada masa ini anakanak mengalami banyak perubahan pada aspek psikis dan fisiknya. Terjadinya perubahan kejiwaan menimbulkan kebingungan di kalangan remaja, sehingga mereka mengalami penuh gejolak emosi dan tekanan jiwa sehingga mudah menyimpang dari aturan dan normanorma sosial yang berlaku di kalangan masyarakat. Di Jakarta, sekitar 70,7\% remaja memiliki pengetahuan yang rendah tentang rokok dan menunjukkan adanya hubungan antara pengetahuan dengan perilaku merokok (Fattah, 2013).

Dampak dari merokok menjadi salah satu masalah kesehatan terbesar di dunia. World Health Organization (WHO) menyatakan bahwa rokok menyebabkan masalah kesehatan yang fatal yang menjadi penyebab kematian kurang lebih 6 juta orang pertahun. Risiko kematian akibat rokok pada perokok aktif lebih tinggi dibandingkan dengan perokok pasif (World Health Organization, 2016).

Hasil dari Riset Kesehatan Dasar DepKes penduduk umur $\geq 10$ tahun menurut provinsi, Jabar Gorontalo Lampung Bengkulu Banten Sulteng Sumbar NTB Malut Sulut Sumsel Kalteng Riau Babel DKI Maluku Aceh Jatim
Jateng Pabar Kalbar Sumut Kepri NTT Kaltara Sultra Kaltim Sulsel Papua Sulbar Jambi Kalsel DIY Bali di tahun 2013 sampai 2018 rokok dihisap setiap hari dan kadang-kadang. RISKESDAS 2013, Prevalensi nasional: 29.3\% RISKESDAS 2018 Prevalensi nasional : 32.8\% Jumlah perokok di seluruh dunia kini mencapai 1,2 milyar orang dan 800 juta diantaranya berada di negara berkembang. Jumlah perokok terbesar di dunia Cina dan India kemudian Indonesia merupakan negara ketiga dengan perokok berat. Berdasarkan Riskesdas tahun 2013 rata-rata perokok saat ini di Indonesia adalah 29,3\%. Proporsi perokok saat ini terbanyak di Kepulauan Riau dengan perokok setiap hari 27,2\%. Berdasarkan hasil GATS 2011 dan Riskesdas 2013 proporsi perokok laki-laki 67,0\% tahun 2011, menjadi 64,9\% tahun 2013. Demikian halnya perokok perempuan yang menurut GATS adalah 2,7\% tahun 2011 dan 2,1\%. Sedangkan untuk rata-rata jumlah batang rokok yang dihisap penduduk umur diatas 10 tahun di Riau sebanyak 16,5\% tahun 2013 (Departemen Kesehatan Republik Indonesia. Hasil Riset Kesehatan Dasar Indonesia, 2013).

Persentase penduduk umur 10 tahun ke atas yang merokok tiap hari $25,4 \%$. Hampir separuh $(48,4 \%)$ penduduk laki-laki umur 10 tahun ke atas merupakan perokok tiap hari.Di Provinsi Sumatera Selatan prevalensi perokok saat ini $31,7 \%$ dengan rerata jumlah rokok yang dihisap 12 batang per hari. Persentase tertinggi usia pertama kali merokok terdapat pada kelompok usia 1519 tahun (34,1\%), disusul usia 10-14 tahun $(10,6 \%)$. Analisis juga menunjukkan $88,1 \%$ perokok merokok di dalam rumah ketika bersama anggota rumah tangga lain. Menurut kelompok umur, pada umumnya jenis rokok yang diminati adalah kretek dengan filter, kecuali pada kelompok umur 55 tahun ke atas kretek tanpa filter merupakan 
pilihannya. Perokok yang masih remaja memiliki status kesehatan yang buruk bila dibandingkana dengan remaja yang tidak merokok merokok sama sekali. Berikut ini paling sering dialami oleh pengguna rokok sebagai berikut sakit kepala, kemudian sakit dibagian punggung yang sering sekali muncul. Selain itu rokok juga telah menjadi salah satu penyebab kematian terbesar di dunia. Adapun penyebab kematian utama para perokok tersebut adalah kanker, penyakit jantung, paru-paru, dan stroke (Saryono, 2014)

Hasil data survey Badan Pusat Statistik dan Dinas Kesehatan Kota Palembang. Perokok di Kota Palembang. No Tahun Prevalensi Perokok di Palembang di tahun 2008 sebesar 10,17\% kemudian pada tahun 2009 naik sebesar $13,17 \%$ di tahun 2010 naik sebesar 5\% menjadi $18,17 \%$ di tahun 2011 di dapatakan hasil sebesar 24,17\% sedangkan pada tahun 2012 sebesar $34,17 \%$ di tahun 2013 sebesar 43,17\% dan di tahun 2014 terjadi kenaikan yang signifikan sebesar $58,17 \%$,Sumber: Survey Badan Pusat Statistik dan Dinas Kesehatan Kota Palembang 5 Selain prevalensi perokok yang setiap tahun terus meningkat, Dinas Kesehatan Kota Palembang juga mencatat jumlah penderita penyakit Infeksi Saluran Pernafasan Akut (ISPA) yang salah satunya disebabkan oleh asap rokok juga mengalami peningkatan, pada bulan Januari 2013 terdapat 13 . 535 orang dan pada tahun 2014 meningkat menjadi 15 . 974 orang. 4 Secara umum faktor yang menyebabkan prevalensi perokok di Kota Palembang terus meningkat yaitu dikarenakan perokok beranggapan bahwa, merokok adalah lambang kedewasaan, percaya diri dan gengsi, obat penghilang kebosanan dan stres. Selain itu karena adanya rasa ingin tahu, mendapatkan rokok masih sangat mudah, terpengaruh teman dan lingkungan, serta kurangnya rasa peduli terhadap risiko bahwa merokok berbahaya bagi kesehatan (DinKes, 2015).

Berdasarkan studi pendahuluan pada tanggal 08 Februari 2019 melalui menyebarkan kuisioner kepada siswa kelas XI IPS yang berjumlah 105 siswa, terdapat 58 siswa laki-laki yang merokok. Sekolah tersebut juga belum pernah mendapatkan pendidikan kesehatan khusus tentang merokok baik dari institusi kesehatan.

Pendidikan kesehatan dapat dilakukan dengan metode dan media yang berbeda-beda (Notoadmojo, 2012). Media digunakan untuk mempermudah penyampaian pesan kepada target pendidikan. Salah satu media yang sering digunakan yakni media leaflet dan poster. Pada media leaflet dan poster ini dapat menampilkan gambar-gambar yang menarik, lebih lengkap, lebih praktis untuk dibawa, mudah dipelajari dimana saja dan juga tidak memerlukan arus listrik yang kadang menjadi kendala pendidikan kesehatan dengan media slide (Notoadmojo, 2012).

Berdasarkan latar belakang dan data-data diatas penulis / peneliti tertarik meneliti apakah ada pengaruh pendidikan kesehatan terhadap pengetahuan dan sikap siswa tentang bahaya merokok di sekolah SMA YWKA di Palembang.

\section{METODE PENELITIAN}

Penelitian ini menggunakan pendekatan pra-eksperimen dengan rancangan (one group pre-post test) (Arikunto, 2013). Tipe penelitian ini adalah menggunakan perbedaan antara sebab akibat dengan cara melibatkan satu kelompok subjek. Kelompok subjek sebelum dilakukan pendidikan kesehatan tentang bahaya merokok terlebih dahulu dilakukan pre-test, kemudian setelah diberikan pendidikan kesehatan dilakukan post-test untuk mengukur kembali pengetahuan dan sikap remaja tentang 
bahaya merokok dengan pengukuran yang sama pada pre-test.

Teknik pengambilan sampel pada penelitian ini dilakukan dengan metode total sampling. Didapatkan jumlah sempel sebanyak 105 siswa

\section{HASIL DAN PEMBAHASAN}

\section{Distribusi Frekuensi Pengetahuan Responden Sebelum dan Sesudah dilakukan Pendidikan Kesehatan}

Tabel 1.

Distribusi Frekuensi Responden Berdasarkan Pengetahuan Sebelum dilakukan Pendidikan Kesehatan

\begin{tabular}{ccccc}
\hline Variabel & Me- & Max & Min & C1 \\
Pengetahuan & dian & & & \\
\hline Sebelum & 73 & 86 & 53 & $\begin{array}{c}68,93- \\
71,49 \\
\end{array}$ \\
Sesudah & 93 & \multirow{2}{*}{100} & 73 & $\begin{array}{c}89,10- \\
91,23\end{array}$ \\
\hline
\end{tabular}

Berdasarkan Tabel 1 diatas dapat dilihat bahwa dari 105 responden, median pengetahuan responden sebelum pendidikan kesehatan adalah 73,00 dan nilai maximum responden sebesar 86 dengan nilai minimum sebesar 53 serta nilai confidence interval 68,93-71,49.

Faktor penyebab yang mempengaruhi pengetahuan seseorang salah satunya adalah faktor informasi, karena kurangnya informasi dapat memperlambat pengetahuan yang diperoleh seseorang.

Penelitian ini sejalan dengan teori yang dikemukakan oleh Notoatmodjo (2012), pendidikan kesehatan merupakan penambahan pengetahuan dan kemampuan seseorang melalui teknik praktik belajar atau instruksi secara individu untuk meningkatkan kesadaran akan nilai kesehatan sehingga dengan sadar mau mengubah perilakunya menjadi perilaku sehat.

Pengetahuan kesehatan seseorang dapat lebih baiksalah satunya yaitu dengan cara melakukan pendidikan kesehatan. Tujuan pendidikan kesehatan yaitu memutuskan kegiatan yang paling tepat guna untuk meningkatkan taraf hidup sehat serta menambah pengetahuan tentang kesehatan (Mubarak, 2012).

Penelitian ini sejalan dengan penelitian yang dilakukan oleh Nuradita (2013) yang berjudul Pendidikan kesehatan yang dilaksanakan di SMP Negeri 3 Kendal memberikan perubahan tingkat pengetahuan siswa tentang bahaya rokok, hal ini terbukti dengan didapatkannya hasil uji statistik menggunakan Marginal Homogeneity Test dengan nilai $\mathrm{p}$ value sebesar 0,000 $(p<0,05)$. Hasil tersebut menujukkan perubahan yang positif tentang tingkat pengetahuan siswa akan bahaya rokok setelah dilakukannya pendidikan kesehatan.

Penelitian ini sejalan dengan penelitian yang dilakukan oleh Puryanto (2012) menghasilkan perbedaan yang signifikan antara sebelum dan sesudah dilakukan pendidikan kesehatan. Pengetahuan siswa setelah dilakukan pendidikan kesehatan semakin meningkat.

Berdasarkan dari nilai median pengetahuan sebelum dilakukan pendidikan kesehatan masih rendah, hal ini karena siswa belum pernah mendapatkan informasi tentang bahaya merokok, sehingga siswa belum mengerti banyak dampak merokok bagi kesehatan, begitu juga responden yang diambil sebagian besar laki-laki, karena minat laki-laki dalam mencari informasi sangat rendah tetapi dalam meniru perilaku lakilaki sangat mudah tertarik sehingga pengetahuan siswa sebelum dilakukan pendidikan kesehatan siswa masih belum mengerti tentang bahaya merokok bagi kesehatan.

Berdasarkan tabel 1 dapat dilihat bahwa dari 105 responden, median pengetahuan responden sesudah pendidikan kesehatan adalah 93,00 dan nilai maximum responden sebesar 100 
dengan nilai minimum sebesar 73 serta nilai confidence interval 89,10-91,23.

Berdasarkan hasil penelitian yang dilakukan pengetahuan responden sesudah dilakukan pendidikan kesehatan di SMA YWKA Palembang didapatkan bahwa dari 105 responden, median pengetahuan responden sesudah pendidikan kesehatan adalah 93,00 dan nilai maximum responden sebesar 100 dengan nilai minimum sebesar 73 serta nilai Confidence Interval 89,10-91,23.

Penelitian ini sejalan dengan teori yang dikemukan oleh penelitian Zulaikah (2012) yang menyebutkan bahwa ada perbedaan yang bermakna pengetahuan tentang bahaya merokok sebelum dan sesudah pemberian pendidikan kesehatan, karena dengan adanya pendidikan kesehatan tentang bahaya merokok siswa yang sebelumnya kurang memahami bahaya merokok secara perlahan pengetahuan siswa terbuka akan tanda bahaya yang ditumbulkan setelah mereka merokok.

Penelitian ini sejalan dengan penelitian yang dilakukan oleh Puryanto (2013) pendidikan kesehatan berpengaruh pada pengetahuan siswa tentang bahaya merokok, hasil uji statistik dengan T-test diperoleh nilai $\mathrm{p}=0,000 \leq \alpha=0,05$, hal ini berarti HO ditolak yang artinya ada pengaruh yang signifikan pada pengetahuan siswa tentang bahaya merokok.

Berdasarkan nilai rata-rata pengetahuan siswa setelah dilakukan pendidikan kesehatan, bahwa pendidikan kesehatan mempengaruhi pengetahuan responden untuk menjadi lebih baik yaitu adanya peningkatan nilai rata-rata responden siswa SMA YWKA Palembang, karena siswa memperhatikan dan mengikuti kegiatan yang diberikan oleh peneliti sehingga informasi yang diberikan oleh peneliti dapat diterima dengan baik oleh responden dan membuat responden lebih memahami tentang bahaya merokok bagi kesehatan.

\section{Distribusi Sikap Responden Sebelum dan Sesudah dilakukan Pendidikan Kesehatan}

Tabel 2.

Disribusi Frekuensi Responden Berdasarkan Sikap Sebelum dilakukan Pendidikan Kesehatan

\begin{tabular}{ccccc}
\hline $\begin{array}{c}\text { Variabel } \\
\text { Sikap }\end{array}$ & $\begin{array}{c}\text { Me- } \\
\text { dian }\end{array}$ & Max & Min & C1 \\
\hline Sebelum & 70 & 90 & 60 & $\begin{array}{c}70,27- \\
\end{array}$ \\
Sesudah & 90 & 100 & 65 & $\begin{array}{c}86,04- \\
\text { (10, }\end{array}$ \\
& & & & 88,91 \\
\hline
\end{tabular}

Berdasarkan Tabel 2 dapat dilihat bahwa dari 105 responden, median sikap responden sebelum pendidikan kesehatan adalah 70,00 dan nilai maximum responden sebesar 90 dengan nilai minimum sebesar 60 serta nilai confidence Interval 70,27-72,87.

Berdasarkan hasil penelitian yang dilakukan, sikap siswa sebelum dilakukan pendidikan kesehatan di SMA YWKA Palembang didapatkan bahwa dari 105 responden, median sikap responden sebelum pendidikan kesehatan adalah 70,00 dan nilai maximum responden sebesar 90 dengan nilai minimum sebesar 60 serta nilai confidence Interval 70,2772,87 .

Penelitian ini sejalan dengan teori yang dikemukakan oleh Robbins (2013) yang mengartikan sikap sebagai suatu pernyataan atau pertimbangan evaluatif mengenai suatu obyek, orang atau peristiwa dimana sikap meliputi tiga komponen yaitu cognitive, affective dan behavior. Selain itu, untuk mengubah sikap, yang perlu diperhatikan adalah kondisi belajar, dimana fasilitator dapat membantu peserta untuk mengenal dan menyadari sikap lama sebelum mengikuti pendidikan kesehatan.

Penelitian ini sejalan dengan penelitian yang dilakukan oleh Fatmawati 
(2013), hasil penelitian nilai rata-rata sikap kelompok control nilai pre test sebesar 40,94 dan berubah menjadi 41,55. Berdasarkan hasil pengujian dikatahui terdapat perbedaan yang bermakna pada sikap responden.

Berdasarkan dari rata-rata sikap sebelum dilakukan pendidikan kesehatan masih rendah, hal ini karena siswa belum pernah mendaptakan informasi tentang bahaya merokok sehingga responden percaya yang dilakukan oleh mereka sudah benar dan tidak merugikan bagi kehidupan mereka. Adapun rata-rata responden adalah laki-laki, sikap sangat berpengaruh pada tingkat emosional seorang laki-laki yang mempunyai kecenderungan untuk bertindak melakukan sesuatu hal seperti merokok dan rata-rata siswa pernah merokok sehingga menimbulkan reaksi yang negatif terhadap kuesioner yang diberikan.

Berdasarkan tabel 2 dapat dilihat bahwa dari 105 responden, median sikap responden sesudah pendidikan kesehatan adalah 90,00 dan nilai maximum responden sebesar 100 dengan nilai minimum sebesar 65 serta nilai confidence interval 86,04-88,91.

Penelitian ini sejalan dengan teori yang dikemukakan oleh Nyswander (2010), pendidikan kesehatan merupakan suatu proses pada diri manusia yang ada hubungannya dengan tujuan kesehatan baik perorangan maupun pada masyarakat. Responden dalam penelitian ini adalah anak-anak sekolah (14-18 tahun). Menurut Notoadmodjo (2012), murid atau anak didik merupakan bibit generasi bangsa yang masih muda menerima, melaksankan, dan mengembangkan ilmu pengetahuan.

Penelitian ini sejalan dengan penelitian yang dilakukan oleh Christina (2012), yang berjudul pengaruh pengetahuan dan sikap guru dan siswa tentang rokok dan kebijakan kawasan tanpa rokok terhadap partisipasi dalam penerapan kawasan tanpa rokok di SMP N 1 Kota Medan tahun 2012, diketahui bahwa hasil uji statistik kai kuadrat dari penelitian tersebut diperoleh $\mathrm{p}$ value 0,009 ( $p$ value $\leq 0,05$ ), artinya ada pengaruh yang signifikan antara sikap terhadap partisipasi dalam penerapan kawasan tanpa rokok.

Berdasarkan dari nilai rat-rata sikap setelah dilakukan pendidikan kesehatan, bahwa pendidikan kesehatan mempengaruhi sikap responden untuk menjadi lebih positif. Kepercayaan yang diberikan responden kepada peneliti dalam pemberian pendidikan kesehatan dengan menggunakan leaflet, power point dan clipt chat dapat menarik perhatian responden sehingga mereka bersemangat dalam mengikuti paparan materi yang diberikan oleh peneliti dan memberikan suatu tnggapan positif terhadap materi yang diberikan.

\section{Perbedaan Pengetahuan Sebelum dan Sesudah Pendidikan Kesehatan Tentang Bahaya Merokok}

Berdasarkan Tabel 3 dapat dilihat bahwa median pengetahuan siswa sebelum pendidikan kesehatan adalah 70,21 dengan median 73,00 dan standar deviasi 6,596 setelah dilakukan pendidikan kesehatan nilai median pengetahuan siswa meningkat yaitu 93,00 dan standar deviasi 5,507. Hasi uji statistik wilcoxon didapatkan nilai $p$ value $=0,000 \quad(p$ value $<0,05)$ artinya ada pengaruh signifikan antara pengetahuan responden sebelum dan sesudah dilakukan pendidikan kesehatan di SMA YWKA Palembang.

Tabel 3.

Perbedaan Pengetahuan Sebelum Dan Sesudah Pendidikan Kesehatan

\begin{tabular}{cccc}
\hline Variabel & Median & SD & p-value \\
\hline $\begin{array}{c}\text { Pengetahun } \\
\text { sebelum }\end{array}$ & 73,00 & 6,596 & \\
\cline { 1 - 2 } $\begin{array}{c}\text { Pengetahun } \\
\text { sesudah }\end{array}$ & 93,00 & 5,507 & 0,000 \\
\hline
\end{tabular}


Perbedaan pengetahuan sebelum dan sesudah dilakukan pendidikan kesehatan tentang bahaya merokok di SMA YWKA Palembang, bahwa rata-rata pengetahuan siswa sebelum pendidikan kesehatan adalah 70,21 dengan median 73,00 dan standar deviasi 6,596 setelah dilakukan pendidikan kesehatan rata-rata pengetahuan siswa meningkat yaitu 90,16 dengan median 93,00 dan standar deviasi 5,507 .

Hasi uji statistik wilcoxon didapatkan nilai $p$ value $=0,000$ ( $p$ value $\leq 0,05)$ artinya ada pengaruh signifikan antara pengetahuan responden sebelum dan sesudah dilakukan pendidikan kesehatan di SMA YWKA Palembang.

Penelitian ini sejalan dengan teori yang dikemukan oleh Notoatmodjo (2012), pendidikan kesehatan merupakan penambahan pengetahuan dan kemampuan seseorang melalui teknik praktik belajar atau instruksi secara individu untuk meningkatkan kesadaran akan nilai kesehatan sehingga dengan sadar mau mengubah perilakunya menjadi perilaku sehat.

Setelah membandingkan penelitian ini dengan penelitian orang lain dan landasan teori yang ada, maka peneliti berpendapat bahwa ada perbedaan pendidikan kesehatan terhadap pengetahuan remaja tentang bahaya merokok, terlihat dari nilai rata-rata responden sebelum dilakukan pendidikan kesehatan masih banyak responden yang belum mengerti tentang bahaya merokok karena kebanyak siswa mendapatkan informasi yang salah tentang rokok, karena mereka beranggapan bahwa dengan merokok dia bisa disebut cowok macco dan lebih percaya diri bila sendang berppasan dengan teman sebayanya, sedangakan rata-rata pengetahuan setelah dilakukan pendidikan kesehatan meningkat karena responden memperhatikan paparan yang dilakukan oleh peneliti.

Penelitian ini sejalan dengan penelitian yang dilakukan oleh Herlina (2013) bahwa pendidikan kesehatan mempengaruhi tingkat pengetahuan siswa tentang bahaya merokok di SMA Negeri 1 Manado, dengan perbedaan nilai rata-rata sebelum diberikan intervensi dan sesudah diberikan intervensi adalah pada siswa kelas X 8,74 dan pada siswa kelas XI 9,00 . Ini membuktikan bahwa pendidikan kesehatan sangat mempengaruhi tingkat pengetahuan siswa tentang bahaya merokok di SMA Negeri 1 Manado.

Penelitian ini dilakukan pendidikan kesehatan dengan media leaflet dan clipt chat, power point serta video tentang bahaya merokok, kemudian peneliti memberikan kesempatan untuk responden untuk bertanya, hal tersebut untuk membantu meningkatkan pengetahuan siswa. Pengetahuan siswa sebelum diberi pendidikan kesehatan siswa masi belum mengerti tentang bahaya merokok bagi kesehatan dan setelah diberikan pendidikan kesehatan melalui media leaflet, clipt chat, power point serta video tentang bahaya merokok siswa mulai memahami tentang bahaya merokok bagi kesehatan.

\section{Perbedaan Sikap Sebelum dan Sesudah Pendidikan Kesehatan Tentang Bahaya Merokok}

Perbedaan sikap sebelum dan sesudah dilakukan pendidikan kesehatan tentang bahaya merokok di SMA YWKA Palembang, bahwarata-rata sikap siswa sebelum pendidikan kesehatan adalah 71,57 dengan median 70,00 dan standar deviasi 6,734 setelah dilakukan pendidikan kesehatan rata-rata sikap siswa meningkat yaitu 87,48 dengan median 90,00 dan standar deviasi 7,407. 
Tabel 4.

Perbedaan Pengetahuan Sebelum Dan Sesudah Pendidikan Kesehatan

\begin{tabular}{cccc}
\hline Variabel & Median & SD & p-value \\
\hline $\begin{array}{c}\text { Sikap } \\
\text { sebelum }\end{array}$ & 70,00 & 6,734 & \\
\cline { 1 - 2 } $\begin{array}{c}\text { Sikap } \\
\text { sesudah }\end{array}$ & 90,00 & 7,407 & 0,000 \\
\hline
\end{tabular}

Hasi uji statistik wilcoxon didapatkan nilai $p$ value $=0,000$ ( $p$ value $\leq 0,05)$ artinya ada perbedaan signifikan antara sikap responden sebelum dan sesudah dilakukan pendidikan kesehatan di SMA YWKA Palembang.

Penelitian ini sejalan dengan teori yang dikemukakan oleh Issnanudin (2012), sikap siswa ini dimungkinkan adanya faktor dari dalam diri siswa, yaitu terjadi penolakan terhadap pernyataan yang dihadapi dalam tes karena siswa perokok aktif sehingga terjadi kontradiksi antara pernyataan dan fenomena.

Berdasarkan penelitian yang dilakukan oleh Yeni (2013), bahwa nilai P $=0,200 \quad(\mathrm{P}>0,05)$ yang berarti data terdistribusi normal. Kemudian diuji dengan independent t-test dan diperoleh nilai $\mathrm{p}=0,79 \quad(\mathrm{P}>0,05)$. Nilai rerata kelompok eksperimen adalah 20,03 dan kelompok control adalah 18,46 dan diartikan bahwa tidak terdapat perbedaan nilai yang bermakna antara kedua kelompok, yaitu kelompok control dan kelompok eksperimen.

Setelah membandingkan penelitian ini dengan penelitian orang lain dan landasan teori yang ada, maka peneliti berpendapat bahwa ada perbedaan pendidikan kesehatan terhadap sikap remaja tentang bahaya merokok, terlihat dari nilai rata-rata sikap responden sebelum melakukan pendidikan kesehatan masih rendah, hal ini dikarenakan banyak siswa yang mempunyai kebiasaan merokok, kurangnya pengetahuan siswa tentang bahaya merokok serta responden memilih mngambil langkah negatif agar dapat diterima dalam kelpmpok pergaulan, sedangkan sesudah dilakukan pendidikan kesehatan dengan menggunaka power point dan pembagian leaflet, seta video dan tulisan motivasi, respon siswa terhadap materi yang diberikan meningkat, hal ini dikarenakan video yang diberikan kepada siswa adalah dampak dari merokok sehingga siswa takut apa yang diberikan bisa terjadi kepada siswa.

\section{KESIMPULAN}

Setelah dilakukan penelitian terhadap 105 responden di SMA YWKA Palembang pada tanggal 15 - 28 Maret 2019, dapat disimpulkan bahwa :

1. Pengetahuan siswa sebelum dilakukan pendidikan kesehatan dengan median sebesar 73,00 dan nilai maximum responden sebesar 86 dengan nilai minimum sebesar 53 serta nilai confidence interval 68,93-71,49.

2. Pengetahuan siswa sesudah dilakukan pendidikan kesehatan dengan median sebesar 93,00 dan nilai maximum responden sebesar 100 dengan nilai minimum sebesar 73 serta nilai confidence interval 89,10-91,23.

3. Sikap siswa sebelum dilakukan pendidikan kesehatan dengan median sebesar 70,00 dan nilai maximum responden sebesar 90 dengan nilai minimum sebesar 60 serta nilai confidence interval 70,27-72,87.

4. Sikap siswa sesudah dilakukan pendidikan kesehatan dengan median sebesar 90,00 dan nilai maximum responden sebesar 100 dengan nilai minimum sebesar 65 serta nilai confidence Interval 86,04-88,91.

5. Terdapat pengaruh pengetahuan dan sikap siswa sebelum dan sesudah dilakukan pendidikan kesehatan dengan nilai $p$ value 0,000 .

Melihat hasil kesimpulan di atas, ada beberapa saran yang perlu diperhatikan dan ditindaklanjuti yaitu diharapkan hasil 
penelitian ini dapat dijadikan rekomendasi bagi peneliti selanjutnya untuk melakukan penelitian, khususnya untuk penelitian tentang bahaya merokok, baik melalui metode penelitian kualitatif ataupun kuantitatif. Media yang digunakan peneliti leaflet dan poster tetapi poster tidak lebih efektif digunakan karena responden fokus dengan leaflet. Disarankan kepada peneliti selanjutnya menggunakan media lain seperti video dan power point. Selain itu diharapkan pihak sekolah dapat mengadakan penyuluhan rutin mengenai bahaya merokok untuk menambah pengetahuan siswa tentang bahaya merokok.

\section{DAFTARPUSTAKA}

Arikunto, S. 2013. Prosedur Penelitian Suatu Pendekatan Praktik. Jakarta : Rineka Cipta

Aziz, H. 2013. Metode Penelitian Keperawatan dan Teknik Analisis Data. Jakarta : Salemba Medika

Azwar. 2013. Reliabilitas dan Validitas. Yogyakarta : Pustaka Balajar Offset

Depkes. 2013. Pedoman Pelaksanaan Kegiatan KIE Kesehatan Reproduksi Untuk Petugas Kesehatan. Jakarta : Departemen Kesehatan

Dian, K. 2009. Faktor-faktor Penyebab Perilaku Merokok Pada Remaja. Yogyakarta : UII Jurnal Keperawatan Anak . Vol 1, No. 1, Mei 2013; 44-4848

Ekowati. 2012. Jumlah Perokok Muda Meningkat. dari http://tempo.co

Juliyah. 2012. Di Indonesia 300 Ribu Kematian Pertahun Akibat Rokok. dari http://infopublik.kominfo.go.id

Kemenkes RI. 2010. Pedoman Teknik Konseling Kesehatan Remaja Bagi Tenaga Kesehatan. Jakarta : Dirjen Bina Kesehatan Masyarakat Kementerian Kesehatan RI

Kristiono. 2008. Perkembangan Psikologi Remaja. dari http://kristiono.wordpress.com Manasikana, Arina. 2009. Hubungan Sikap Remaja Tentang Merokok Dengan Perilaku Merokok Remaja Di SMP 3 Patebon Kabupaten Kendal. Kendal : STIKES Kendal Mubarok. Remaja dan Perilaku Merokok. dari http://id.shvoong.com/medicine-andhealth/1928293-remaja-danperilakumerokok.html

Muladi, A. 2010. Pelayanan Kesehatan Peduli Remaja (PKPR). dari http://www.infodokterku.com

Mu'tadin, Z. 2012. Remaja dan Rokok. dari http://www.e-psikologi.com/remaja/ 050602.htm.

Notoatmodjo, S. 2012. Pendidikan Dan Perilaku Kesehatan. Jakarta : Rineka Cipta .

Perry dan Potter. 2013 .Buku Ajar Fundamental Keperawatan : Konsep, Proses, dan Praktik. Edisi 4. Jakarta : EGC

Puryanto. 2012. Pengaruh Pendidikan Kesehatan Terhadap Pengetahuan dan Sikap Siswa Tentang Bahaya Rokok. Semarang : STIKES Telogorejo

Putri. 2010. Hubungan Antara Tingkat Pengetahuan Tentang Rokok Terhadap Perilaku Merokok Pada Siswa Kelas II SMK Bhinneka Patebon Kendal. Kendal : STIKES Kendal

Sarwono. 2002. Sosiologi Kesehatan dan Beberapa Kasus Beserta Aplikasi. Yogyakarta : Gajah Mada University Press

Sudjana. 2012. Desain dan Analisis Eksperimen Jilid 4. Bandung : Tarsito Bandung

Sugiyono. 2013. Statistika Untuk Penelitian. Bandung : Alfabeta 
Sutrisno, H. 2013. Metodologi Research 2. Yogyakarta : Yayasan Fakultas Psikologi Universitas Gajah Mada Yogyakarta

Tisna. 2009. Perkembangan Sosial dan Bahasa Remaja. Diakses tanggal 12 September

2012 dari http://tisna2008.wordpress.com

Triswanto, SD. 2007. Stop Smoking.Yogyakarta : Progresif Books.

Udiyono, A. 2014. Metodologi Penelitian Kesehatan. Semarang : UNDIP.

Yusuf, I. 2013. Makalah Seminar Seksualitas Di Kalangan Remaja

Alhamda, S. dan Sriani, Y. 2015. Buku Ajar Ilmu Kesehatan Masyarakat. Yogyakarta:

Deepublish. Aliansi Pengendalian Tembakau Indonesia (APTI). 2013. Peta Jalan

Pengendalian Produk Tembakau Indonesia. Surakarta: Muhammadiyah University Press.

Bachtiar, M. Y. 2015. Perbedaan Pengetahuan pada Pendidikan Kesehatan Metode Ceramah dan Media Leaflet dengan Metode Ceramah dan Media Video Tentang Bahaya Merokok di SMK Kasatrian Solo. Naskah Publikasi. Surakarta: Universitas Muhammadiyah Surakarta.

Dahlan, M. S. 2008. Statistik untuk KedokterandanKesehatan. Edisi ketiga. Jakarta: Salemba Medika.

Daryanto. 2011. Media Pembelajaran. Bandung: Nurani Sejahtera. Dinas Kesehatan Karanganyar, 2014. Mapping Perilaku Merokok Rumah Tangga di Karanganyar: APDB tahun 2014

Effendy, N. 1998. Dasar-Dasar Keperawatan Kesehatan Masyarakat. Jakarta: EGC.

Herijulianti, E., Indriani, T.S., dan Artini, S. 2002. Pendidikan Kesehatan Gigi. Jakarta: EGC.

Ikhsan, H., Arwani, dan Purnomo. 2013. Pengaruh Pendidikan Kesehatan Bahaya Merokok terhadap Perilaku Mengurangi Konsumsi Rokok pada Remaja. Karya Ilmiah S.1 Ilmu Keperawatan. Semarang: Poltekes Semarang.

Mohamad, F., Prabandari, Y. S., dan Priyanto, A. 2012. Peningkatan Pengetahuan dan Sikap terhadap Bahaya Rokok bagi Kesehatan Melalui Poster dengan Partisipasi Siswa di Kabupaten Gorontalo. Berita Kedokteran Masyarakat, Vol. 28, No. 1, hlm. 20-26.

Mudjiono, 2009. Belajar dan Pembelajaran. Jakarta. Rineka Cipta

Notoatmodjo. S. 2012. Promosi Kesehatan dan Perilaku Kesehatan. Jakarta: Rineka Cipta

Oktavia, D. 2011. Faktor-Faktor yang Berhubungan dengan Tindakan Merokok Siswa Laki-Laki di SMA Negeri Kota Padang Tahun 2011. Skripsi. Padang: Universitas Andalas.

Suiraoka, I.P., dan Supariasa, I.D. 2012. Media Pendidikan Kesehatan. Yogyakarta: Graha Ilmu

Wahyuni, L. 2016. Efektifitas Health Education (HE) Media Booklet tentang Bahaya Merokok terhadap Tingkat Pengetahuan Remaja di SMPN 1 Mojoanyar. Jurnal Penelitian Kesehatan, Vol. 13, No. 1, hlm. 1-13.

Zulaekah, S. 2012. Pendidikan Gizi dengan Media Booklet terhadap Pengetahuan Gizi. Jurnal Kesehatan Masyarakat (Kemas), Vol. 7, No. 2, hlm. 127-133. 